\title{
Ebola is causing moral distress among African healthcare workers
}

\author{
Hundreds of local healthcare workers have died in west African settings that lack the resources to \\ deal with the Ebola outbreak, writes Connie M Ulrich
}

\author{
Connie M Ulrich associate professor of bioethics and nursing, School of Nursing, Department of \\ Medical Ethics and Health Policy and the New Courtland Center for Transitions and Health, University \\ of Pennsylvania, Philadelphia, Pennsylvania 19106, USA
}

\begin{abstract}
No one is talking about what must be profound moral distress among local African healthcare workers. Moral distress can result from not acting in accordance with what you believe to be ethically correct in professional practice, and it can lead to serious health related outcomes such as emotional suffering and physical ailments. ${ }^{1-3}$ The phenomenon was first described by the philosopher Andrew Jameton 30 years ago. ${ }^{1}$

It is common to hear clinicians say, "I didn't do right in that situation." Moral distress is increasingly common among healthcare clinicians both nationally and internationally and can occur when doctors and nurses feel powerless to voice their concerns, do not agree with treatment procedures, or lack the equipment or resources necessary to advocate for patients. It can manifest as a sense of dread and a feeling of a loss of professional integrity. Many of us in healthcare can easily remember specific cases that led to feelings of moral distress. Perhaps we were questioning the continued use of aggressive measures requested by family members against the advice of the medical team. Or perhaps we were struck by a parent's emotional insistence to keep his or her critically ill child alive at all costs. Or perhaps we were in the middle of a contentious family conflict that could not be resolved. For example, some evidence reports that $27 \%$ of European and Israeli intensive care clinicians cite inappropriateness of care in at least one patient care situation; in a similar way, higher moral distress in US physicians and nurses is associated with pressure to continue "unwarranted aggressive treatment." ${ }^{5}$ However, for African healthcare workers this distress often centres on an inability to meet an overwhelming demand for basic patient care needs with limited supplies and other resources. ${ }^{6}$
\end{abstract}

\section{Emotional work}

Healthcare is emotional work. Doctors and nurses share some of the most intense situations in patients' lives. We bear witness to pain, suffering, conflict, and dying every day.
This of course is also the case in western Africa. Local healthcare workers know what needs to be done but simply do not have adequate resources to support all the immediate care needs of people infected with Ebola. They are overwhelmed with sick patients, becoming sick themselves, and, in many instances, dying too. In fact, more than 300 healthcare workers have died to date. ${ }^{7}$ The immense moral, physical, and psychological consequences of Ebola are obvious.

Ebola has heightened our senses to the daily plight of physicians and nurses, but in west Africa fear is rampant. Local services are short staffed, conditions are crowded, and healthcare workers have to be sprayed down for decontamination. In some instances they are too afraid to come to work at all.

Should clinicians protect themselves and their immediate family members from harm by walking away from their patients? Or should they remain at the bedside even if they know that they do not have the necessary equipment to "do good" for all patients? What if that means they suffer the same fate themselves? Either way, it is morally distressing.

Some local healthcare workers refused to care for infected patients. Such "conscientious objection" may be ethically justified where the risk is imminently greater than the benefit that can be brought. ${ }^{8}$ Doctors and nurses deserve protective equipment, up to date information, and universal policies that guide opting out for workers who might be at particular risk.

Stopping the spread of Ebola is an urgent and universal priority. It requires a density of well trained and equipped clinicians. Profound shortages of doctors, nurses, and midwives have undermined the ability of some African countries to meet the United Nations' millennium development goals.

The Ebola virus brings this stark reality to the fore. Once this epidemic is over, we will need to examine the many ethical questions that have surfaced. What do we owe global societies during an epidemic in terms of medical, nursing, and economic relief? How do we serve those who have served others by 
supporting their health and wellbeing? How do we guarantee that local caregivers are equipped as adequately as foreign aid workers? And, how do we minimise moral distress among doctors and nurses who are already working under extreme circumstances and with limited resources to meet their professional and ethical obligations to patients?

\section{Human vulnerability}

The United Nations Human Development Report 2014 says that "persistent vulnerability threatens human development, and unless it is systematically tackled by policies and social norms, progress will be neither equitable nor sustainable." "The vulnerability of African healthcare workers is all too real. They have seen at first hand the degradation, death, and suffering of their citizens from diseases such as HIV, malaria, tuberculosis, and others; now they are living through Ebola.

Tackling global moral distress will not be easy. Advocating for practice environments that allow all doctors and nurses to meet their ethical obligations in clinical care is our collective social responsibility as members of unique professional groups that serve the public good.

The words of Albert Camus, from his novel The Plague, speak well of African local healthcare workers' resolve, resiliency, and commitment to patient care in the face of extreme adversity: "I have no idea what's awaiting me, or what will happen when this all ends. For the moment I know this: there are sick people and they need curing." 10
And, most immediately, they are in need of caring.

CMU acknowledges Christine Grady for her thoughtful comments. Competing interests: I have read and understood the BMJ policy on declaration of interests and have no relevant interests to declare.

Provenance and peer review: Not commissioned; not externally peer reviewed.

1 Jameton A. Nursing practice: the ethical issues. Prentice-Hall, 1984.

2 Ulrich C, O'Donnell P, Taylor C, Farrar A, Danis M, Grady C. Ethical climate, ethics stress, and the job satisfaction of nurses and social workers in the United States. Soc Sci Med 2007;65:1708-19.

3 Ulrich CM, Taylor C, Soeken K, O'Donnell P, Farrar A, Danis M, et al. Everyday ethics: ethical issues and stress in nursing practice. J Adv Nurs 2010;66:2510-9.

4 Piers RD, Azoulay E, Ricou B, Dekeyser Ganz F, Decruyenaere J, Max A, et al. Perceptions of appropriateness of care among European and Israeli intensive care unit nurses and physicians. JAMA 2011;306:2694-703.

5 Hamric AB, Blackhall LJ. Nurse-physician perspectives on the care of dying patients in intensive care units: collaboration, moral distress, and ethical climate. Crit Care Med 2007;35:422-9.

6 Harrowing JN, Mill J. Moral distress among Ugandan nurses providing HIV care: a critical ethnography. Int J Nurs Stud 2010:723-31.

7 World Health Organization (WHO). Ebola response roadmap situation report. 5 November 2014. http://apps.who.int/iris/bitstream/10665/137510/1/roadmapsitrep_5Nov14_eng.pdf.

8 Bradley I. Conscientious objection in medicine: A moral dilemma. Clinical Correlations 28 May 2009. www.clinicalcorrelations.org/? $p=1454$.

9 Malik K. The 2014 human development report: sustaining human progress: reducing vulnerabilities and building resilience. http://hdr.undp.org/sites/default/files/hdr14-reporten-1.pdf.

10 Camus A. The Plague. New York, Vintage Books, 1991.

Cite this as: BMJ 2014;349:g6672

(c) BMJ Publishing Group Ltd 2014 